\title{
Solvent-Induced Hearing Loss from Occupational Exposure in Asia: A systematic review
}

\author{
Mohd Shukri Bin Mohd Aris ${ }^{1}$, Ainul Naqueah Zainal Abidin², \\ Ailin Razali ${ }^{3}$, Norazura Ismail ${ }^{4}$, Adrian Fuente ${ }^{5}$ \\ ${ }^{1}$ Faculty of Health Sciences, Universiti Teknologi MARA, 42300 Bandar Puncak Alam, Selangor, Malaysia, ${ }^{2}$ Faculty of Occupational \\ Safety and Health, University of Cyberjaya, 63000 Cyberjaya, Selangor, Malaysia, ${ }^{3}$ Faculty of Medicine, International Islamic \\ University Malaysia, 25200 Kuantan, Pahang, Malaysia, ${ }^{4}$ Faculty of Industrial Sciences and Technology, University Malaysia Pahang, \\ Lebuhraya Tun Razak, 26300 Kuantan, Pahang, Malaysia, ${ }^{5}$ Faculty of Medicine, University of Montreal, Quebec, Canada.
}

myshukri@uitm.edu.my, ainulnaqueah91@gmail.com, ailin@iium.edu.my, zuraismail@ump.edu.my, adrian.fuente@umontreal.ca. Tel of $1^{\text {st }}$ Author: 012-3761808

\begin{abstract}
Exposure to certain solvents in the workplace can cause hearing loss. This study aims to bring attention to the existing literature on the adverse effects of solvents on workers' auditory function in a diverse occupational setting. The literature search used in this study is PubMed and Web of Science. $87 \%$ of the selected studies reported that the highest prevalence of hearing loss was from solvents and noise-exposed groups. Evidence shows that interaction between the solvent and the noise could be both additive and synergistic. More epidemiology studies on solvent-induced hearing loss using diverse approaches are warranted in the Asia region.
\end{abstract}

Keywords: hearing loss; solvent; pure tone audiometry; chemical-induced hearing loss

eISSN: 2398-4287@ 2021. The Authors. Published for AMER ABRA cE-Bs by e-International Publishing House, Ltd., UK. This is an open access article under the CC BYNC-ND license (http://creativecommons.org/licenses/by-nc-nd/4.0/). Peer-review under responsibility of AMER (Association of Malaysian Environment-Behaviour Researchers), ABRA (Association of Behavioural Researchers on Asians/Africans/Arabians) and CE-Bs (Centre for Environment-Behaviour Studies), Faculty of Architecture, Planning \& Surveying, Universiti Teknologi MARA, Malaysia.

DOI: https://doi.org/10.21834/ebpj.v6i17.2872

\subsection{Introduction}

Hearing loss is the fourth highest cause of disability globally, with an approximate annual cost of over 750 billion dollars (Cunningham and Tucci, 2017). People with Occupational Noise-Related Hearing Disorders (ONRHD) are around 466 million people. Based on World Health Organization (WHO) projection, the number will increase up to $36 \%$ by 2030. Moreover, the number is expected to grow up to 900 million people by 2050 unless action is taken. Noise could not be assumed as the only ultimate risk factor that causes hearing loss as nowadays, chemicals are undeniably contributing to the current prevalence of hearing loss worldwide (WHO, 2018). According to Audiology Information Series (2015), certain chemicals could cause hazardous effects on hearing.

These chemicals are called ototoxic chemicals. The ototoxic substance includes solvent (organic and inorganic), pesticides, pharmaceuticals, asphyxiants, nitriles, heavy metals, and compounds (NIOSH Safety and Health Information Bulletin, 2018). When comparing solvent-exposed workers to non-exposed workers, human studies have found that solvent-exposed workers had a greater rate of hearing loss (Fuente \& McPherson, 2012). Despite the existence of some data on ototoxic exposure in specific industries, little

eISSN: 2398-4287@ 2021. The Authors. Published for AMER ABRA cE-Bs by e-International Publishing House, Ltd., UK. This is an open access article under the CC BYNC-ND license (http://creativecommons.org/licenses/by-nc-nd/4.0). Peer-review under responsibility of AMER (Association of Malaysian Environment-Behaviour Researchers), ABRA (Association of Behavioural Researchers on Asians/Africans/Arabians) and CE-Bs (Centre for Environment-Behaviour Studies), Faculty of Architecture, Planning \& Surveying, Universiti Teknologi MARA, Malaysia.

DOI: https://doi.org/10.21834/ebpj.v6i17.2872 
is known about who is the population at risk and more crucially, who is at a higher risk of co-exposure due to workplace noise (Lewkowski et al. 2019).

\subsection{Purpose of the study}

The purpose of this study was to highlight and provide the up-to-date current state of the research on solvent-induced hearing loss in Asia.

\subsection{Objective of the study}

The objective of this study was to explore the available scientific literature on the adverse effects of solvents on workers' auditory function in a diverse occupational setting in Asia. It examines the existing research in Asia on the impact of occupational exposure to solvents or solvent mixtures towards hearing impairment.

\subsection{Literature Review}

According to Kwon J.K \& Lee J., (2021), the direct impact of solvents on the cells of the organ of Corti, resulting in the disruption of their membranous structures, would be the mechanism of acute damage, whereas the development of chemically and physiologically reactive intermediates might explain chronic ototoxic consequences.

Hemmativaghef (2020) also claimed that solvent could cause the formation of chemical and biological reactive intermediate, including reactive oxygen species, which may trigger the death of the organ of Corti. Therefore, when acoustic energy enters the cochlea with an organic solvent, it may be more damaging, resulting in high-tone sensorineural hearing loss. Chemical poisoning can occur when the solvents flow through the stria vascularis and reach the outer hair cells without creating mechanical stress. Loud noise, on the other hand, caused mechanical damage to the cochlea. The positive interaction effect between solvent and noise was due to the increased production of oxidative stress (Hsu et al. 2015).

Several studies have documented the ototoxicity of the solvent mixture, noise plus solvent mixture, and toluene plus noise (Hsu et al., 2015; Lewkowski et al., 2019; Staudt et al., 2019, Hemmativaghef, 2020). A study found a significant association between organic solvent (toluene, benzene, and ethylbenzene) and high-frequency hearing loss whereby the estimated effect is higher than the audiometrically assessed (Staudt et al. 2019).

\subsection{Methodology}

\section{.1 Data sources}

Two search engines PubMed and Web of Science (WoS) were used in this review. The search included peer-reviewed articles published in English from the year 2000 until 2021. The literature search was done with the following keywords: solvent OR chemical AND (Hearing loss) OR (hearing impairment) OR (hearing disorder) OR (auditory dysfunction) AND (Occupational exposure) OR workers OR employee OR workplace AND Ototoxicity OR Ototoxicant OR cochleotoxicants OR vestibulotoxicants). Reference from identified studies was scanned to identify any other relevant research. A set of criteria was established to select relevant studies (Table 1).

Table 1. Inclusion and exclusion criteria

\begin{tabular}{lll}
\hline \multicolumn{1}{c}{ Criterion } & \multicolumn{1}{c}{ Inclusion } & \multicolumn{1}{c}{ Exclusion } \\
\hline Time & Year 2000 onwards & Year 1999 and below \\
Article type & Peer-reviewed & Non-peer reviewed \\
Language setting & English & Non-English \\
Exposure setting & Occupational & Non-occupational \\
Type of study & Human studies & Animal studies \\
Hazard exposure & Solvent exposure & Heavy metal, pharmaceutical drugs, asphyxiants, nitriles. \\
Participant & Occupational workers & Non-occupational workers \\
Country & Asia & Other than Asia countries \\
\hline
\end{tabular}

\subsection{Findings}

\subsection{Description of excluded studies}

Initial keyword search identified 125 studies (see Figure 1). A total of 61 studies were excluded composed of duplicate studies ( $n=43$ ), systematic review, letter, book chapter, case report, case series $(n=15)$, non-occupational exposure studies $(n=3)$. After initial exclusion, a total of 64 studies were retrieved for further screening. The inclusion and exclusion criteria specified in Table 1 were not met by 49 of the 64 studies. Full-text copies from the fifteen remaining studies were used in this study, and the following data were extracted: hazard exposure, study design, sample size, industrial setting, audiological procedure, and the outcome. 


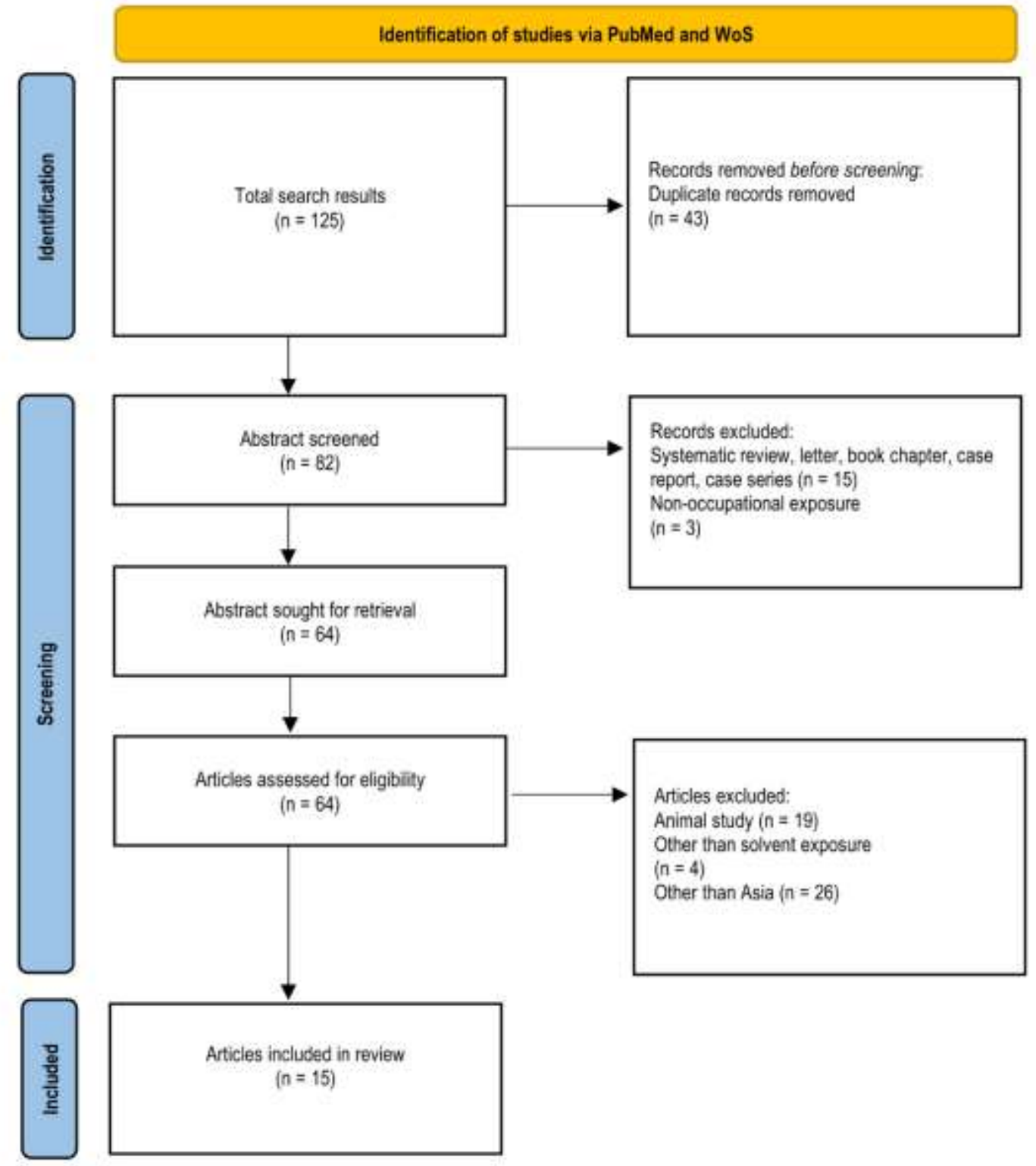

Fig 1: Flow chart of the studies identification and selection process.

\subsection{Description of selected studies}

\subsubsection{Study design}

This review consists of fifteen studies from various occupational settings that were eligible for final review composed of twelve $(n=12)$ cross-sectional studies (Morioka I. et al. 2000; Chang et al. 2003; Kim J. et al. 2005; Chang et al. 2006; Mohammadi S. et al. 2010; Beshir, Elserougy \& Amer 2011; Zhang et al. 2013; Choi Y.H \& Kim K. 2014; Loukzedeh Z. et al. 2014; Kaewboonchoo et al. 2014; Yang H.Y et al. 2016; Choochouy et al. 2019). Three $(n=3)$ retrospective case-control studies (Rizk and Sharaf, 2010; Metwally et al. 2011; Unlu et al. 2014).

\subsubsection{Industrial setting}

The selected studies in this review were from Plastic button factory (Morioka I. et al. 2000); viscose rayon plant (Chang et al. 2003); aviation industry (Kim J. et al. 2005); adhesive material manufacturing industry (Chang et al. 2006); automobile plant (Mohammadi S. et al. 2010) and (Unlu et al. 2014); fermentation plant factory (Rizk and Sharaf, 2010); ceramic factory (Beshir, Elserougy \& Amer 2011); paint industry (Metwally et al. 2011); petrochemical industry (Zhang et al. 2013); nationwide industrial workers (Choi Y.H \& Kim 
K. 2014); petroleum-distillate-producing industry (Loukzedeh Z. et al. 2014); Naval Officer (Kaewboonchoo et al. 2014); stone processing industry (Yang H.Y et al. 2016); conventional farmers and organic farmers (Choochouy et al. 2019).

\subsubsection{Auditory Assessment method}

Exposure to all substances studied primarily uses Pure Tone Audiometry (PTA; $n=15)$, Otoscopic Examination ( $n=2)$, Otopharyngeal Examination $(n=1)$ to measure the study's outcome.

\subsubsection{Hazard exposure and the Outcome}

Eleven $(n=11)$ studies evaluated the combined auditory effect of noise and organic solvents mixture (Morioka I. et al. 2000; Kim J. et al. 2005; Mohammadi S. et al. 2010; Rizk and Sharaf 2010; Beshir, Elserougy \& Amer 2011; Metwally et al. 2011; Unlu et al. 2014; Kaewboonchoo et al. 2014; Loukzedeh Z. et al. 2014; Yang H.Y et al. 2016; Choochouy et al. 2019). One study ( $n=1$ ) evaluated the combined effect of noise, organic solvents mixture, and a mixture of heavy metals (Choi Y.H \& Kim K. 2014). The rest of the studies evaluated the combined effect of noise and carbon disulfide, CS2 (Chang et al. 2003), toluene (Chang et al. 2006), and ethylbenzene (Zhang et al. 2013) individually.

Thirteen out of 15 studies ( $n=13$ ) demonstrate a significant increase in hearing loss from the exposure of "solvent and noise", "solvent mixture and noise" and "solvent mixture, heavy metal mixture, and noise" compared with the control groups (Morioka I. et al. 2000; Chang et al. 2003; Kim J. et al. 2005; Chang et al. 2006; Mohammadi S. et al. 2010; Rizk et al. 2010; Metwally et al. 2011; Beshir, Elserougy \& Amer 2011; Zhang et al. 2013; Unlu et al. 2014; Choi Y.H \& Kim K. 2014; Yang H.Y et al. 2016; Choochouy et al. 2019).

Two $(n=2)$ studies related to organic solvent mixture found no association between the organic solvent mixture and hearing impairment (Loukzedeh Z. et al. 2014; Kaewboonchoo et al. 2014). Table 2 shows the highlighted part of the research, hazard exposure, study design, sample size, industrial setting, audiological procedure, and the outcomes.

Table 2. Highlighted part of the research.

\begin{tabular}{|c|c|c|c|c|c|c|}
\hline Author & $\begin{array}{c}\text { Hazard } \\
\text { exposure }\end{array}$ & $\begin{array}{l}\text { Study place } \\
\text { / design }\end{array}$ & $\begin{array}{c}\text { No. of } \\
\text { participants }\end{array}$ & Industrial setting & $\begin{array}{c}\text { Audiological } \\
\text { procedure }\end{array}$ & Outcome \\
\hline Morioka I. et al. (2000) & $\begin{array}{l}\text { Styrene 3.7-46.3 } \\
\text { ppm; methanol 2.9- } \\
\text { 135ppm; methyl } \\
\text { acetate 2.5- } \\
\text { 93.8ppm; } \\
\text { Noise 58-92dB(A) }\end{array}$ & $\begin{array}{l}\text { Japan / cross- } \\
\text { sectional study }\end{array}$ & Total: 54 & $\begin{array}{l}\text { Plastic button } \\
\text { factory }\end{array}$ & PTA $0.5-8 \mathrm{kHz}$ & $\begin{array}{l}\text { The combined group had a } \\
\text { significantly greater prevalence of } \\
\text { hearing loss }(25 \%) \text { than the noise- } \\
\text { only group and the control group. }\end{array}$ \\
\hline Chang et al. (2003) & $\begin{array}{l}\text { Carbon disulphide } \\
\text { 1.6-20.1ppm. } \\
\text { Noise } 80-91 \mathrm{~dB}(\mathrm{~A})\end{array}$ & $\begin{array}{l}\text { Taiwan / } \\
\text { cross- } \\
\text { sectional } \\
\text { study }\end{array}$ & Total: 346 & Viscose rayon plant & PTA $0.5-6 \mathrm{kHz}$ & $\begin{array}{l}\text { Hearing loss }>25 \mathrm{~dB} \text { is more } \\
\text { common in rayon workers }(67.9 \%) \\
\text { than in administrative }(23.6 \%) \text { and } \\
\text { electronic employees }(32.4 \%) \text {. } \\
\text { Hearing loss showed the most } \\
\text { severe at frequency } 6 \mathrm{kHz} \text { and the } \\
\text { least at } 2 \mathrm{kHz} \text {. }\end{array}$ \\
\hline Kim J. et al. (2005) & 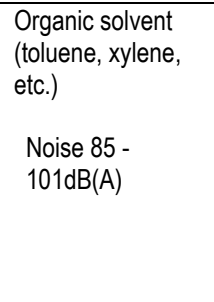 & $\begin{array}{l}\text { Korea / cross- } \\
\text { sectional } \\
\text { study }\end{array}$ & Total: 328 & Aviation industry & PTA 0.5-8kHz & $\begin{array}{l}\text { Prevalence of hearing loss of noise } \\
\text { plus solvent-exposed group ( } 54.9 \%) \\
\text { was higher than other groups; } 6 \% \\
\text { unexposed, } 17.1 \% \text { noise only, } \\
27.8 \% \text { solvent only. } \\
\text { RR } 8.1 \text { (noise plus solvent group), } \\
4.3 \text { (noise-only group), } 2.6 \text { (solvent- } \\
\text { only group). }\end{array}$ \\
\hline Chang et al. (2006) & $\begin{array}{l}\text { Toluene 33-164.6 } \\
\text { ppm } \\
\text { Noise } 69.9-90.1 \\
\text { dB(A). }\end{array}$ & $\begin{array}{l}\text { Taiwan / } \\
\text { cross- } \\
\text { sectional } \\
\text { study }\end{array}$ & Total: 174 & $\begin{array}{l}\text { Adhesive material } \\
\text { manufacturing } \\
\text { workers. }\end{array}$ & $\begin{array}{l}\text { PTA 0.5-6kHz } \\
\text { Otopharyngeal } \\
\text { examination }\end{array}$ & $\begin{array}{l}\text { The prevalence of hearing loss } \\
>25 \mathrm{~dB} \text { in the toluene plus noise } \\
\text { group }(86.2 \%) \text { was significantly } \\
\text { higher than in the noise only } \\
(44.8 \%) \text { and administrative } \\
\text { personnel groups }(5 \%) \text {. } \\
\text { Poorest hearing threshold } 4-6 \mathrm{kHz}\end{array}$ \\
\hline Rizk and Sharaf (2010) & $\begin{array}{l}\text { Toluene, xylene, } \\
\text { butyl acetate, ethyl } \\
\text { alcohol } \\
\text { Noise } 54- \\
107.5 \mathrm{~dB}(\mathrm{~A})\end{array}$ & $\begin{array}{l}\text { Egypt / } \\
\text { retrospective } \\
\text { case-control } \\
\text { study }\end{array}$ & Total: 140 & $\begin{array}{l}\text { Fermentation plant } \\
\text { factory }\end{array}$ & $\begin{array}{l}\text { PTA 4kHz v- } \\
\text { notch }\end{array}$ & $\begin{array}{l}36 \% \text { exposed group suffered } \\
\text { hearing loss compared to the } \\
\text { control group }(33 \%), p<0.001 \text {. }\end{array}$ \\
\hline
\end{tabular}




\begin{tabular}{|c|c|c|c|c|c|c|}
\hline $\begin{array}{l}\text { Mohammadi S. et al. } \\
\text { (2010) }\end{array}$ & $\begin{array}{l}\text { Toluene } 19-31 \\
\mathrm{mg} / \mathrm{m}^{3} ; \mathrm{xylene} \\
137-388 \mathrm{mg} / \mathrm{m}^{3} ; \\
\text { benzene } 0.003- \\
2.012 \mathrm{mg} / \mathrm{m}^{3} \\
\\
\text { Noise } 75-88 \mathrm{~dB}(\mathrm{~A})\end{array}$ & $\begin{array}{l}\text { Tehran / } \\
\text { cross- } \\
\text { sectional } \\
\text { study }\end{array}$ & Total: 441 & Automobile plant & PTA $0.5-8 \mathrm{kHz}$ & $\begin{array}{l}\text { A significant association between } \\
\text { hearing loss and mix organic } \\
\text { solvent even within recommended } \\
\text { exposure limit. } \\
\text { High-frequency hearing loss range } \\
4,6 \text { and } 8 \mathrm{kHz} \text {. }\end{array}$ \\
\hline Metwally et al. (2011) & $\begin{array}{l}\text { Toluene 142- } 182 \\
\mathrm{mg} / \mathrm{m}^{3} ; \mathrm{xylene} \\
232-314 \mathrm{mg} / \mathrm{m}^{3} ; \\
\text { other solvents } \\
\text { Noise } 68.2- \\
\text { 87.1dB(A) }\end{array}$ & $\begin{array}{l}\text { Egypt / } \\
\text { Retrospective } \\
\text { case-control } \\
\text { study }\end{array}$ & Total: 222 & Paint industry & PTA $0.5-8 \mathrm{kHz}$ & $\begin{array}{l}\text { Statistically significant different } \\
\text { hearing loss between study groups } \\
(p<0.01) \text {. } \\
\text { The noise plus solvent group had a } \\
\text { higher prevalence of sensory neural } \\
\text { hearing loss }(43 \%) \text { than the noise- } \\
\text { only group }(23.4 \%) \text {. }\end{array}$ \\
\hline $\begin{array}{l}\text { Beshir, Elserougy \& } \\
\text { Amer (2011) }\end{array}$ & $\begin{array}{l}\text { Organic solvent } \\
\text { mixture } \\
\text { Toluene, xylene, } \\
\text { acetone, ethanol, } \\
\text { butanol, ethyl } \\
\text { acetate, } \\
\text { isopropranolol } \\
\text { Noise 48-83dB(A) }\end{array}$ & $\begin{array}{l}\text { Egypt / Cross- } \\
\text { sectional } \\
\text { study }\end{array}$ & Total: 204 & Ceramic factory & $\begin{array}{l}\text { PTA 0.25- } \\
8 \mathrm{kHz}\end{array}$ & $\begin{array}{l}\text { Solvent plus noise-exposed group } \\
\text { significantly higher auditory } \\
\text { threshold compared to control } \\
\text { group. } \\
\text { At high frequencies ( } 4 \text { and } 8 \mathrm{kHz} \text { ), } \\
\text { the solvent group exhibited a strong } \\
\text { positive connection with the } \\
\text { exposure time. }\end{array}$ \\
\hline Zhang et al. (2013) & $\begin{array}{l}\text { Ethylbenzene } \\
122.83-134.64 \\
\mathrm{mg} / \mathrm{m}^{3} \\
\\
\text { Noise 67.3.- } \\
\text { 84.3dB(A) }\end{array}$ & $\begin{array}{l}\text { China / cross- } \\
\text { sectional } \\
\text { study }\end{array}$ & Total: 1170 & $\begin{array}{l}\text { Petrol chemical } \\
\text { plant }\end{array}$ & $\begin{array}{l}\text { PTA 0.5-8kHz } \\
\text { Otoscopic } \\
\text { examination }\end{array}$ & $\begin{array}{l}\text { The prevalence of hearing loss is } \\
\text { much higher in petrol chemical } \\
\text { groups }(78.4 \% \text { and } 80.1 \%) \text { than in } \\
\text { the power station (56.9\%) and } \\
\text { control group ( } 5.2 \%) \text {. } \\
\text { Compared with the control group, } \\
\text { OR petrochemical groups were } 107 \\
(95 \% \mathrm{Cl}=17.1 \text { to } 358) \text { and } 114 \\
(95 \% \mathrm{Cl}=34.2 \text { to } 343) \text {, about four } \\
\text { times higher than that of } 27.5(95 \% \\
\mathrm{Cl}=6.4 \text { to } 63.2) \text { in the power } \\
\text { station group, respectively. }\end{array}$ \\
\hline $\begin{array}{l}\text { Choi Y.H \& Kim K. } \\
\text { (2014) }\end{array}$ & 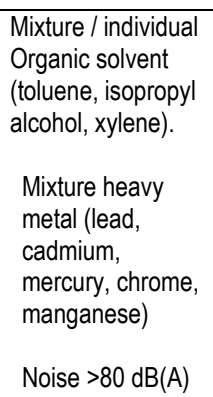 & $\begin{array}{l}\text { Korea /cross- } \\
\text { sectional } \\
\text { study }\end{array}$ & Total: 30,072 & Industrial workers & PTA 0.5-6KHz & $\begin{array}{l}\text { Individuals exposed to heavy } \\
\text { metal plus organic solvent had } \\
1.64 \text { to } 2.15 \text { times higher PTA } \\
\text { increment with occupational noise } \\
\text { exposure. } \\
\text { Higher increment organic solvent } \\
\text { at } 3,4 \text { and } 6 \mathrm{kHz} \text {; heavy metal } \\
\text { exposed group at } 2 \text { and } 3 \mathrm{kHz} \text {. }\end{array}$ \\
\hline
\end{tabular}




\begin{tabular}{|c|c|c|c|c|c|c|}
\hline $\begin{array}{l}\text { Loukzedeh Z. et al. } \\
\text { (2014) }\end{array}$ & $\begin{array}{l}\text { Organic solvent } \\
\text { (toluene, xylene, } \\
\text { benzene) } \\
\text { Noise }<75 \mathrm{~dB}(\mathrm{~A})\end{array}$ & $\begin{array}{l}\text { Iran / Cross- } \\
\text { sectional } \\
\text { study }\end{array}$ & Total: 182 & $\begin{array}{l}\text { Petroleum-distillate- } \\
\text { producing industry }\end{array}$ & PTA $0.5-8 \mathrm{kHz}$ & $\begin{array}{l}\text { No significant association between } \\
\text { solvent exposure and hearing loss. }\end{array}$ \\
\hline Unlu et al. (2014) & $\begin{array}{l}\text { Toluene } 26- \\
33 \mathrm{mg} / \mathrm{m}^{3}, \text { benzene } \\
0.98-1.86 \mathrm{mg} / \mathrm{m}^{3}, \\
\text { xylene } 265- \\
411 \mathrm{mg} / \mathrm{m}^{3}, \\
\text { tetrachloroethylene } \\
43-51 \mathrm{mg} / \mathrm{m}^{3}, \\
\text { acetone } 98-182 \\
\mathrm{mg} / \mathrm{m}^{3} \text {. } \\
\text { Noise } 78-87 \mathrm{~dB}(\mathrm{~A})\end{array}$ & $\begin{array}{l}\text { Turkey / } \\
\text { Retrospective } \\
\text { case-control } \\
\text { study }\end{array}$ & Total: 588 & $\begin{array}{l}\text { Bus and truck } \\
\text { manufacturing } \\
\text { plant. }\end{array}$ & PTA $0.5-8 \mathrm{kHz}$. & $\begin{array}{l}\text { Hearing loss was increased in the } \\
\text { solvent plus noise-exposed group in } \\
\text { the range } 2-8 \mathrm{kHz} \text {. } \\
\text { The prevalence of hearing loss is } \\
\text { higher in the solvent plus noise } \\
\text { group compared to other groups. }\end{array}$ \\
\hline $\begin{array}{l}\text { Kaewboonchoo et al. } \\
\text { (2014) }\end{array}$ & $\begin{array}{l}\text { Organic solvent } \\
\text { mixture; toluene } \\
0.18-0.32 \mathrm{ppm} ; \\
\text { xylene } 0.12-0.15 \\
\text { ppm, ethyl acetate } \\
0.40-0.70 \mathrm{ppm} \text {, } \\
\text { butyl acetate } 0.09 \text { - } \\
0.11 \mathrm{ppm} \text {, and } \\
\text { cyclohexanone } \\
0.13-0.29 \mathrm{ppm} \\
\\
\text { Noise } 62.2-104.7 \\
\mathrm{~dB}(\mathrm{~A})\end{array}$ & $\begin{array}{l}\text { Thailand / } \\
\text { cross- } \\
\text { sectional } \\
\text { study }\end{array}$ & Total: 149 & Naval Officers & PTA $0.5-8 \mathrm{kHz}$ & $\begin{array}{l}39.6 \% \text { of Naval Officers had hearing } \\
\text { loss. } \\
\text { Hearing loss was linked to people } \\
\text { who were over } 39 \text { years old and } \\
\text { had more than } 8 \text { years of job } \\
\text { experience. }\end{array}$ \\
\hline
\end{tabular}




\begin{tabular}{|c|c|c|c|c|c|c|}
\hline Yang H.Y et al. (2016) & $\begin{array}{l}78 \text { Volatile organic } \\
\text { solvent (toluene, } \\
\text { acetate, butane, } \\
\text { etc.) } \\
\text { Noise } 87.7 \mathrm{~dB}(\mathrm{~A})\end{array}$ & $\begin{array}{l}\text { Taiwan / } \\
\text { cross- } \\
\text { sectional } \\
\text { study }\end{array}$ & Total: 314 & $\begin{array}{l}\text { Stone processing } \\
\text { industry workers. }\end{array}$ & $\begin{array}{l}\text { PTA 0.2- } \\
20 \mathrm{kHz}\end{array}$ & $\begin{array}{l}\text { Prevalence of hearing loss increase } \\
\text { in the epoxy exposed group ( } 42 \% \text { ) } \\
\text { compared to the non-epoxy } \\
\text { exposed group ( } 21 \%) \text {, } \\
\text { administrative staff group (9.3\%). } \\
\text { Significantly increased risk of } \\
\text { hearing loss in the epoxy adhesive } \\
\text { exposed group between } 2-6 \mathrm{kHz} \\
\text { (interaction observed at } 3,4, \& \\
6 \mathrm{kHz} \text {.) }\end{array}$ \\
\hline Choochouy et al. (2019) & $\begin{array}{l}\text { Insecticide } 0.07, \\
>2.407 \text { (score- } \\
\text { year) } \\
\text { Organophosphate } \\
0.09,->1.118 \\
\text { (score-year) } \\
\\
\text { Noise } 61.8- \\
92.7 \mathrm{~dB}(\mathrm{~A})\end{array}$ & $\begin{array}{l}\text { Thailand / } \\
\text { Cross- } \\
\text { sectional } \\
\text { study }\end{array}$ & Total: 335 & $\begin{array}{l}\text { Conventional } \\
\text { farmers and } \\
\text { organic farmers }\end{array}$ & $\begin{array}{l}\text { PTA 0.5-6kHz } \\
\text { Otoscopic } \\
\text { examination }\end{array}$ & $\begin{array}{l}\text { Cumulative exposure from groups } \\
\text { insecticide, organophosphate, and } \\
\text { noise was associated with an } \\
\text { increased high-frequency hearing } \\
\text { threshold in conventional farmers. } \\
\text { Prevalence abnormal hearing } \\
\text { (>25dB) is higher in the high- } \\
\text { frequency band (3-6kHz) than in the } \\
\text { lower band }(0.5-2 \mathrm{kHz}) \text {. }\end{array}$ \\
\hline
\end{tabular}

\subsection{Discussion}

\subsection{Exposure of Workers to Solvent and Noise}

The prevalence of hearing loss of $\geq 25 \mathrm{~dB}$ in the group with concurrent exposure to noise and CS2 (Chang et al. 2003), toluene (Chang et al. 2006), and ethylbenzene (Zhang et al. 2013) was considerably higher in the solvent-exposed group than that in the two comparison groups, the noise-only group, and the control group.

Studies have proven that the noise plus solvent mixture exposed group seem to have the highest rate of hearing loss compared to the solvent only and unexposed groups, despite the level of noise (Metwally et al. 2011; Unlu et al. 2014) level of each organic solvent (Kim J. et al. 2005; Morioka I. et al. 2000; Metwally et al. 2011; Unlu et al. 2014; Yang H.Y et al. 2016) lower than the level recommended limit and threshold limit value (TLV). There was also a significantly higher auditory threshold shift in the solvent and noise-exposed group than the control group, although the concentration solvent mixture was lower than the level recommended limit and threshold limit value (TLV) (Beshir, Elserougy \& Amer,2011).

On the contrary, Kaewboonchoo et al. (2014) reported that only age and service experience were significantly associated with hearing loss. This is due to the fact the highest exposure solvent level was only $1.6 \%$ from the exposure limit. A similar finding was also reported by Loukzedeh Z. et al. (2014), who pointed that there was no significant association between solvent exposure and high-frequency and low-frequency hearing loss. This might be due to the noise level at all sites was $75 \mathrm{~dB}$, much lower than the permissible exposure limit and the mean work duration was less than four years. M. Śliwińska-Kowalska et al. (2005) also found that the risk of hearing loss was not increased by short-term (four years) exposure to a low-concentration mixture of chemicals.

Ten reported studies $(n=10)$ confirmed a synergistic effect of solvent and noise exposure (Morioka I. et al. 2000; Chang et al. 2003; Kim J. et al. 2005; Chang et al. 2006; Mohammadi S. et al. 2010; Rizk and Sharaf 2010; Metwally et al. 2011; Zhang et al. 2013; Unlu et al. 2014; Yang H.Y et al. 2016). These studies confirmed an increased effect of combined exposure of noise and solvent compared to noise alone. Similarly, Kim J. et al. (2005) concluded that noise and solvent have a multiplicative synergistic effect.

Two studies ( $n=2$ ) confirmed that there was an additive effect of solvent exposure and noise. Choochouy et al. (2019) claimed that there was an additive effect between pesticide and noise exposure since the model in this study did not show any synergistic effect. The same results were also obtained by Choi Y.H. and Kim K. (2014), who claimed that noise exposure is the main cause of hearing loss and the ototoxic chemicals may have an additional impact in low-noise environments. However, there was no accessible measurable data for the solvent and heavy metal in that study as they were classed as exposed or not exposed.

High-frequency hearing loss is more common in the solvent plus noise-exposed group compared to noise only and solvent only group (Morioka I. et al. 2000; Kim J. et al. 2005; Mohammadi S. et al. 2010; Metwally et al. 2011; Beshir, Elserougy \& Amer, 2011; Choi Y.H. and Kim K. (2014); Unlu et al. 2014). Loukzedeh Z. et al. 2014). Beshir, Elserougy \& Amer (2011) reported that when comparing the solvent group and the noise group, hearing loss is more common at $8 \mathrm{kHz}$ than $4 \mathrm{kHz}$ in the solvent group, while in the noise group, $4 \mathrm{kHz}$ is more common than $8 \mathrm{kHz}$. Rizk and Sharaf (2010) who studied workers in a fermentation plant factory revealed that there was a significantly higher proportion of v-notch among solvent mixture and noise group than the non-exposed at $4 \mathrm{k} \mathrm{Hz}$. On the other hand, 
two studies claimed that there was a significant interaction between solvent mixture and noise were observed in mid and high frequency (3-6 kHz) (Yang H.Y et al. 2016; Choochouy et al. 2019).

The pattern of hearing impairment associated with concurrent exposure of noise and CS2 (Chang et al. 2003) and toluene (Chang et al. 2006) were similar. Both investigations discovered that the most significant effect at lower frequencies of $0.5 \mathrm{to} 2 \mathrm{kHz}$. When compared to noise alone, both solvent-exposed groups show a more significant impact on speech frequency. However, the results were most likely caused by conductive hearing loss as sound may not reach the inner ear due to an obstruction or damage to the outer or middle ear that prevents sound from being conducted to the inner ear.

\subsection{Implication and the Knowledge Gaps.}

Only $27 \%$ of studies have conducted pure-tone air and bone conduction audiometry, capable of distinguishing between conductive and sensorineural hearing loss. Therefore, most studies could not truly confirm that the hearing losses were due to solvent exposure. Due to this fact, this is a systematic review with the diversity of outcome measures within the Asia region, the potential underlying reason should have come into consideration.

Understanding the type of hearing loss and the equipment required to improve auditory reception is critical in addressing hearing loss. One way to distinguish between conductive and sensorineural hearing loss is by comparing air-conduction and bone-conduction hearing threshold levels. According to Rowe \& O'Leary (2014), air-conduction thresholds provide only limited information on auditory disorders. The bone-conduction testing thresholds are needed to determine whether an auditory impairment is conductive or cochlear (sensorineural) or both (mixed).

Since air conduction audiometry is the most widely used audiometry test for screening occupational hearing loss, it is insufficient to use results based on this screening audiometry to diagnose the type of hearing loss. Thus, air-conduction audiometry should always be complemented with bone-conduction audiometry to critically distinguish between conductive and sensorineural hearing loss. Researchers could also consider a more sensitive test, the Otoacoustic Emission to complement PTA. This test can detect hearing loss one phase earlier compared to PTA and could differentiate whether it is a sensory hearing disorder or neural hearing disorder.

\subsection{Conclusion \& Recommendations}

It can be concluded that concurrent exposure of solvent and noise might cause synergistic and additive interaction. Therefore, in the case of a combination of exposure, the permissible exposure limit for each noise and solvent should be lowered than the existing permissible limit. Employees exposed to ototoxic solvents must be included in the Hearing Conservation Program (HCP). However, it is also important to note that in most of the reported cases where potential ototoxic was identified, the actual sensorineural diagnosis could not be made certain as the studies did not mention specific bone conduction tests being done in the methodology. More epidemiology studies on the hearing effect from solvent exposure using a diverse approach are warranted to let the underlying cause of the problem be diagnosed.

\section{Acknowledgment}

This research was funded by IIUM-UMP-UiTM Sustainable Research Collaboration. The authors declare no conflict of interest related to this research.

\section{Paper Contribution to Related Field of Study}

This study provided the up-to-date current state of the research on solvent-induced hearing loss in Asia and analyzed the interaction effect of simultaneous noise and solvent exposure.

\section{References}

Adrian Fuente and Bradley McPherson (2012). Occupational Chemical-Induced Hearing Loss, Hearing Loss, Dr. Sadaf Naz (Ed.), ISBN: 978-953-51-0366-0, InTech, Available from: http://www.intechopen.com/books/hearing-loss/occupational-chemical-induced-hearing-loss.

Chang, S. J., Chen, C. J., Lien, C. H., \& Sung, F. C. (2006). Hearing loss in workers exposed to toluene and noise. Environmental Health Perspectives, 114(8), 12831286. https://doi.org/10.1289/ehp.8959

Chang, S. J., Shih, T. S., Chou, T. C., Chen, C. J., Chang, H. Y., \& Sung, F. C. (2003). Hearing loss in workers exposed to carbon disulfide and noise. Environmental Health Perspectives, 111(13), 1620-1624. https://doi.org/10.1289/ehp.6289

Choi, Y. H., \& Kim, K. S. (2014). Noise-induced hearing loss in Korean workers: Co-exposure to organic solvents and heavy metals in nationwide industries. PLoS ONE, 9(5), 1-8. https://doi.org/10.1371/journal.pone.0097538

Choochouy, N., Kongtip, P., Chantanakul, S., Nankongnab, N., Sujirarat, D., \& Woskie, S. R. (2019). Hearing Loss in Agricultural Workers Exposed to Pesticides and Noise. Annals of Work Exposures and Health, 63(7), 707-718. https://doi.org/10.1093/annweh/wxz035

Cunningham, L. L. and Tucci, D. L. (2017) 'Hearing Loss in Adults', New England Journal of Medicine, 377(25), pp. 2465-2473. doi: 10.1056/NEJMra1616601. 
http://www.nejm.org/doi/10.1056/NEJMra1616601.

Hemmativaghef, E. (2020). Exposure to lead, mercury, styrene, and toluene and hearing impairment: evaluation of dose-response relationships, regulations, and controls. Journal of Occupational and Environmental Hygiene, 17(11-12), 574-597. https://doi.org/10.1080/15459624.2020.1842428

Hsu, P. C., Cheng, P. W., \& Young, Y. H. (2015). Ototoxicity from organic solvents assessed by an inner ear test battery. Journal of Vestibular Research: Equilibrium and Orientation, 25(3-4), 177-183. https://doi.org/10.3233/VES-150559

Joong-Keun Kwon and Jiho Lee (March 25th 2021). Occupational Hearing Loss, Hearing Loss - From Multidisciplinary Teamwork to Public Health, Tang-Chuan Wang IntechOpen, DOI: 10.5772/intechopen.97109. Available from: https://www.intechopen.com/chapters/75934\#B76

Kaewboonchoo, O., Srinoon, S., Lormphongs, S., Morioka, I., \& Mungarndee, S. S. (2014). Hearing loss in Thai naval officers of coastal patrol crafts. Asia-Pacific Journal of Public Health, 26(6), 651-659. https://doi.org/10.1177/1010539513510552

Kim, J., Park, H., Ha, E., Jung, T., Paik, N., \& Yang, S. (2005). Combined effects of noise and mixed solvents exposure on the hearing function among workers in the aviation industry. Industrial Health, 43(3), 567-573. https://doi.org/10.2486/indhealth.43.567

Lewkowski, K., Heyworth, J. S., Li, I. W., Williams, W., Mccausland, K., Gray, C., Ytterstad, E., Glass, D. C., Fuente, A., Si, S., Florath, I., \& Fritschi, L. (2019). Exposure to noise and ototoxic chemicals in the Australian workforce. Occupational and Environmental Medicine, 76(5), 341-348. https://doi.org/10.1136/oemed-2018-105471

Loukzadeh, Z., Shojaoddiny-Ardekani, A., Mehrparvar, A. H., Yazdi, Z., \& Mollasadeghi, A. (2014). Effect of exposure to a mixture of organic solvents on hearing thresholds in petrochemical industry workers. Iranian Journal of Otorhinolaryngology, 26(77), 235-243. https://doi.org/10.22038/ijorl.2014.2866

Metwally, F. M., Aziz, H. M., Mahdy-Abdallah, H., Elgelil, K. S. A., \& El-Tahlawy, E. M. (2012). Effect of combined occupational exposure to noise and organic solvents on hearing. Toxicology and Industrial Health, 28(10), 901-907. https://doi.org/10.1177/0748233711427051

Mohammadi, S., Labbafinejad, Y., \& Attarchi, M. (2010). Combined effects of ototoxic solvents and noise on hearing in automobile plant workers in Iran. Arhiv Za Higijenu Rada i Toksikologiju, 61(3), 267-274. https://doi.org/10.2478/10004-1254-61-2010-2013

Morioka, I., Miyai, N., Yamamoto, H., \& Miyashita, K. (2000). Evaluation of combined effect of organic solvents and noise by the upper limit of hearing. Industrial Health, 38(2), 252-257. https://doi.org/10.2486/indhealth.38.252

Organization, W. H. (2018). Addressing The Rising Prevalence of Hearing Loss. In World Health Organization: Geneva, Switzerland (Issue February). https://apps.who.int/iris/bitstream/handle/10665/260336/9789241550260eng.pdf?sequence=1\&ua=1\%0Ahttp://www.hear-

it.org/multimedia/Hear_It_Report_October_2006.pdf\%0Afile://C:/Users/E6530/Downloads/9789-240685215_eng.pdf\%0Ahttp://dx.doi.org/10.1016/j.ijpor

Occupational Safety and Health Administration, \& National Institute for Occupational Safety and Health. (2018). Preventing Hearing Loss Caused by Chemical (Ototoxicity) and Noise Exposure. Safety and Health Information Bulletin. 1-5.

Rizk, S. A., \& Sharaf, N. E. (2010). Health hazards among a sample of workers exposed to a combination of noise and organic solvents in a fermentation factory in Egypt. 8(6), 95-99.

Rowe, D. P., \& O'Leary, S. J. (2014). Auditory System, Peripheral. Encyclopedia of the Neurological Sciences, 1, 329-334. https://doi.org/10.1016/B978-0-12-385157$4.00121-4$

Safia Beshir, A., Elserougy, S. M., \& Amer, N. M. (2011). Ototoxic and ototraumatic effects of organic solvents and occupational noise in ceramic workers. Australian Journal of Basic and Applied Sciences, 5(12), 21-28

Series, I. (2015). Audiology Information Series Chemical Exposure Effects on Hearing and Balance AUDIOLOGY.

Sliwinska-Kowalska M, Zamyslowska-Szmytke E, Szymczak W, et al. Exacerbation of noise-induced hearing loss by co-exposure to workplace chemicals. Environmental Toxicology and Pharmacology. 2005 May;19(3):547-553. DOI: 10.1016/j.etap.2004.12.018. PMID: 21783525

Staudt, A. M., Whitworth, K. W., Chien, L. C., Whitehead, L. W., \& Gimeno Ruiz de Porras, D. (2019). Association of organic solvents and occupational noise on hearing loss and tinnitus among adults in the U.S., 1999-2004. International Archives of Occupational and Environmental Health, 92(3), 403-413.

Unlu, I., Kesici, G. G., Basturk, A., Kos, M., \& Yilmaz, O. H. (2014). A comparison of the effects of solvent and noise exposure on hearing, together and separately. Noise and Health, 16(73), 410-415. https://doi.org/10.4103/1463-1741.144422

Yang, H. Y., Shie, R. H., \& Chen, P. C. (2016). Hearing loss in workers exposed to epoxy adhesives and noise: A cross-sectional study. BMJ Open, 6(2) https://doi.org/10.1136/bmjopen-2015-010533

Zhang, M., Wang, Y., Wang, Q., Yang, D., Zhang, J., Wang, F., \& Gu, Q. (2013). Ethylbenzene-induced hearing loss, neurobehavioral function, and neurotransmitter alterations in petrochemical workers. Journal of Occupational and Environmental Medicine, 55(9), 1001-1006. https://doi.org/10.1097/JOM.0b013e31829f3142 